Sharp, A. (1960): The discovery of the Pacific Islands. Oxford University Press, 259 p. シーボルト (1832)・ 中井晶夫訳 (1977) : 日本, 第 1 巻, 雄松堂, $414 \mathrm{p}$.

\title{
2.3 硫黄島の地質
}

\author{
大八木規夫* 井口隆*
}

\section{Geology of Iwo-jima}

Norio OYAGI and Takashi INOKUCHI

\begin{abstract}
The main portion of Iwo-jima island consists of lava flows and pyroclastic rocks of trachy andesite, erupted and deposited in shallow sea, except the upper part of Suribachiyama, in 2600-2800 y.B.P. The island have been uplifting from about 800 y.B.P., followed by active faulting and change in coast lines.
\end{abstract}

\section{I. 地 質 概 観}

本島は陸上部に注目すれば，元山，晢鉢山および両者を継ぐ千鳥ケ原の 3 地区に大別される。元山地区 は，2．2節で明らかなように，直径約 $10 \mathrm{~km}$ のカルデラを有する大きな火山体の中央火口丘に相当し，颃 鉢山はその側火山であると考えられる。また干鳥ケ原の大部分は元山火山堆積物の南西への延長である (後述)。

本島の地質図は第 1 章第 3 図に示した。これは一色（1976）の地質図に筆者らの知見を加筆したもので ある。以下, 本島の地質構成を概観する。

元山地区は粗面安山岩溶岩と同質の火砕岩から構成されている(一色 1976)。粗面安山岩溶岩は東海岸 の海食崖から潮干帯にかけて広い分布が認められている(本間 1925, KRAUSKOPT 1948, CORWIN and FOSTER 1959，一色 1976)。筆者らは1980年の調査によって北部の為八海岸海食崖でも幅300mに わたる露頭を見出した。元山台地上でも東部および中央部に 3 個所で小規模な分布が知られている。また, 1982年国土朾による元山地区中央部北部における深さ $150 \mathrm{~m}$ の試錐結果によると（2．4節参照）媣さ $25 \mathrm{~m}$ 以下に 3 枚の溶岩が火砕岩と互層をなすことが認められている。その最上位のものは厚さ $70 \mathrm{~m}$ あ, 海食 崖に露出する溶岩に連続する可能性も大きい。本溶岩は暗灰色で一部は黒曜石状を呈し, 流理構造を持つ 部分も認められる（写真 1)。一色（1976）は枕状構造を見出し, 溶岩の噴出は海中で行われたと考えた。

この粗面安山岩溶岩の上位に厚い火砕岩が分布し, 津屋によって元山凝灰岩（津屋 1936a）, または Motoyama bluff tuff（津屋 1936b）と呼ばれている。本岩は元山地区のほとんど全域を覆っている。そ の岩相は現生，および離水した海食崖において良く観察できる。

この火砕岩は溶岩直上にある最下部から上部へ, 集塊岩状の粗粒部から次第に細粒化しており, 東海岸 の海食崖において，一色（1976）は上部層と下部層に大別している。下部層は, 大まかな層理のみられる, 淘汰の悪い集塊岩ないし軽石角碩岩で,「大型の火山弾を含む」,「本質岩塊としては軽石が主体で」「他に

* 国立防災科学技術センター National Research Center for Disaster Prevention 


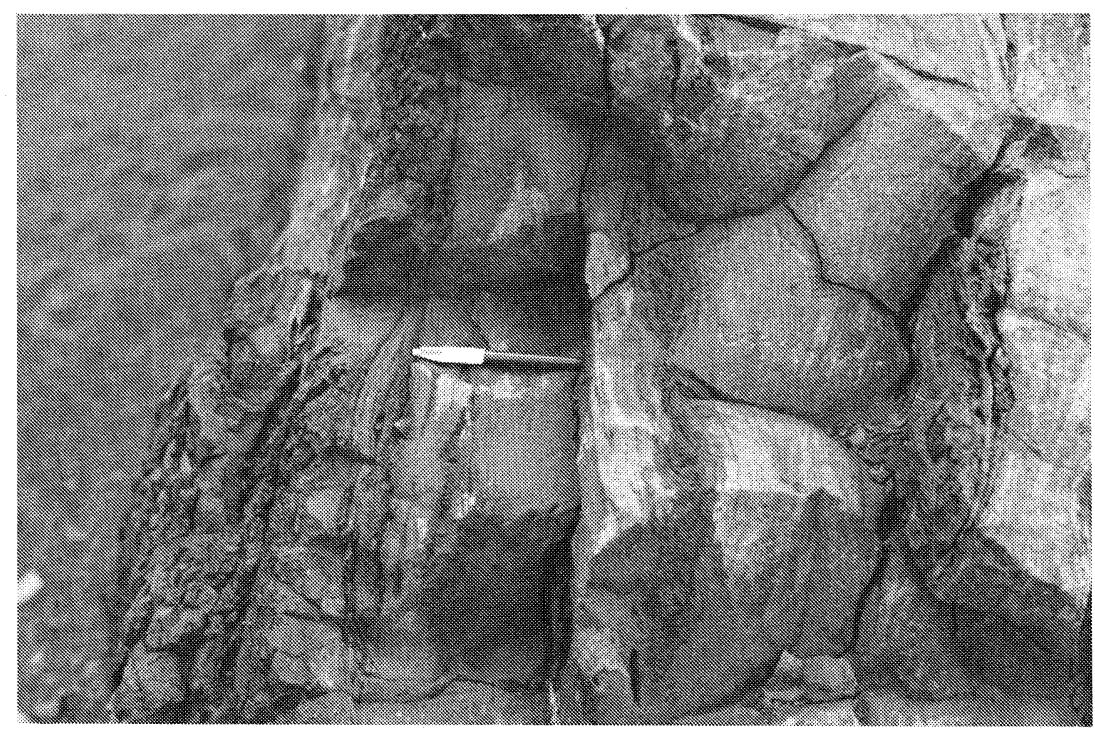

写真 1 流理構造を持つ元山溶岩 箱庭浜付近

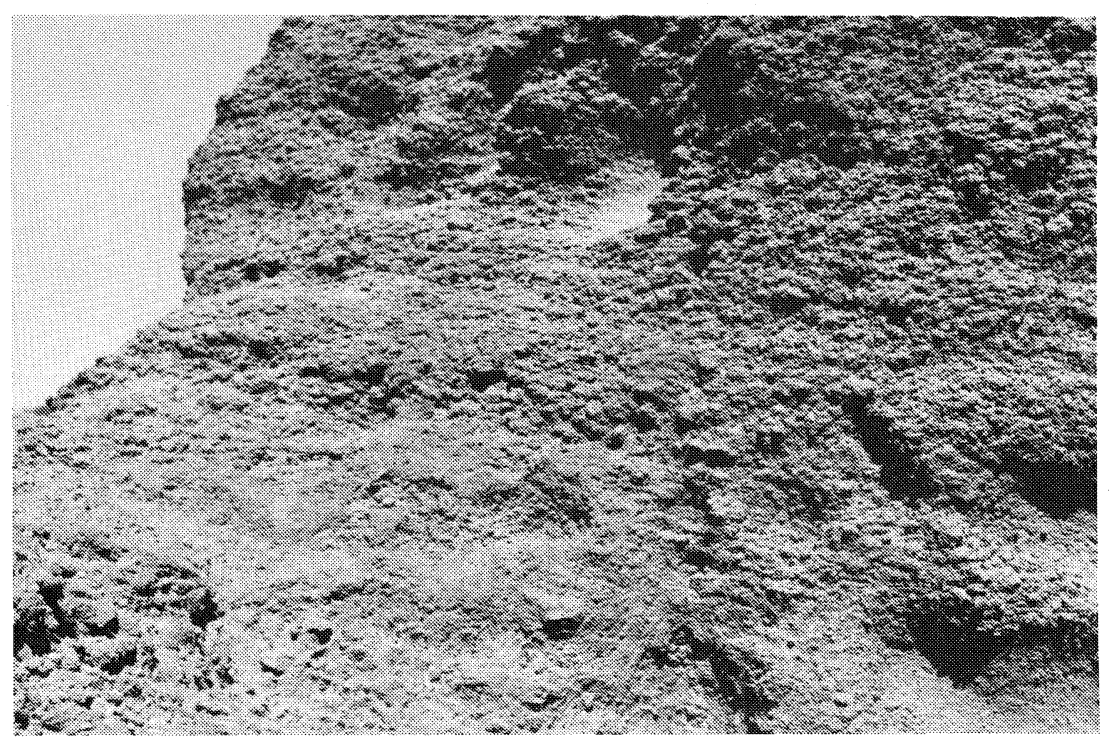

写真 2 元山火砕岩（下部層）

不規則な形の黒曜石片」がある。下部層は灰色を呈し，上部層は褐色を呈している。上部層は細粒で層理 む明膫になり, 級化成層も認められる。最上部は細粒ガラス質凝灰岩である。下部層は未固結に近くハン マーやシャベルで掘りやすい。しかし，上部層は半固結ないし固結している。固結のバインダーは沸石に よる（一色 1976）。

上部層と下部層との境界面は層理面と斜交しているところがある（一色 1976）。

一色（1976）は集塊岩が溶岩流表面の凹所を埋め立てるように堆積していること，凝灰岩中の級化成層 


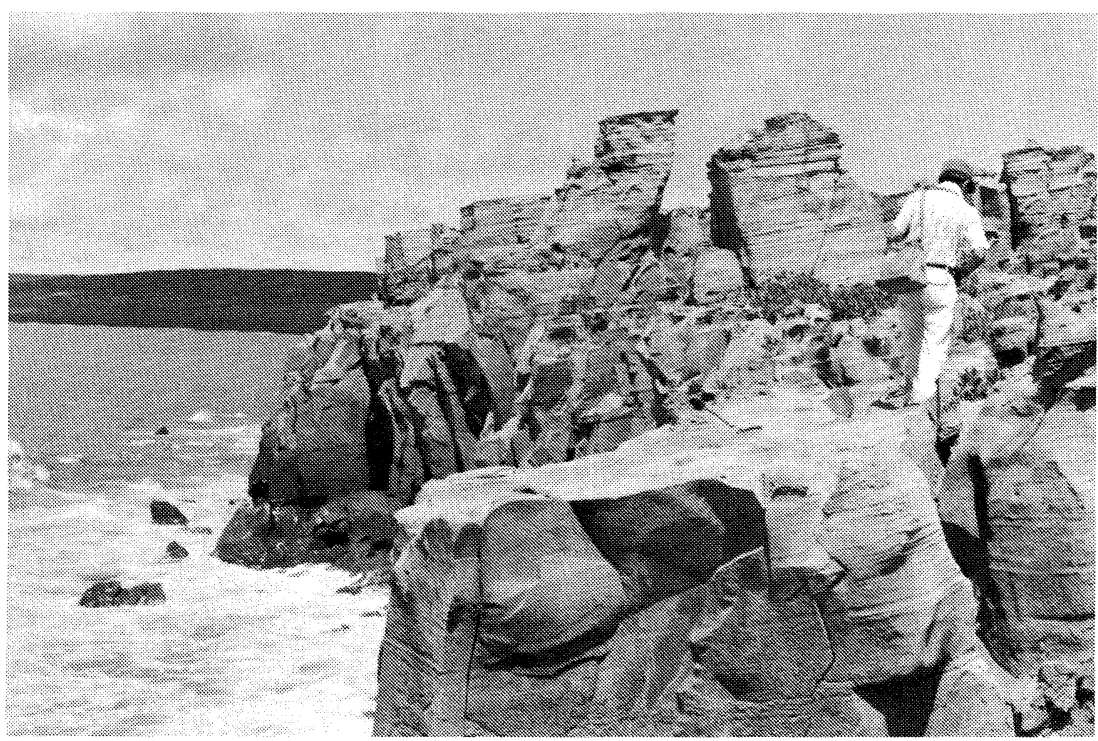

写真 3 元山火砕岩 (上部層) 神山海岸 層理は海に向ってゅるく傾斜している。

構造，コンボルート葉理および斜層理などから火砕岩全体も水中堆積層と考えた。ところで，大八木・熊 谷（1977）は北の鼻海岸において，火砕岩の上部層と下部層の境界付近に炭化木片の産出層準を発見し， この層準は下部層の頂部は一時的に陸化して, 漂流木片が汀線付近で打上げ混入し，その直後，細粒な上 部層が堆積したと考えた $\left({ }^{14} \mathrm{C}\right.$ 年代については後述)。

粗面安山岩溶岩と火砕岩との関倸については, 津屋 (1936a) と一色（1976）の見解は大きく異なる。津 屋元山北東海岸製塩所南東方海食崖の露頭に捻いて，粗面安山岩が凝灰岩に貫入していると述へ， スケ ッチを示している。しかし，一色は同地点と思われる金剛岩南西 $200 \mathrm{~m}$ の旧海食崖を調查し，これは貫入関 係ではなく，火砕岩が溶岩をアバットの関係で覆ったものと考えた。なお，一色は溶岩表面が侵食を受け ていない事から両者の時間間隙は短いとしている。

筆者らは1980年，為八海岸に溶岩の新産地を発見し，その西端部で溶岩と火砕岩が複雑に入り組んでい る露頭を見い出した。すなわち，溶岩の一部が火砕岩の巨大なブロックをとり込むように不規則な脈状に 広がっている（写真 4 ）。その一方で，火砕岩は溶岩の上位に分布すると同時に，長く引き伸ばされた溶 岩片（写真 5 ) を含んでいる。これらの観察から，両者の関係は純粋な貫入関係や不整合ではなく，王 んど同時生成を示すものと考える。溶岩の噴出に始まった活動は，溶岩が完全に固結する以前に大量の火 砕物噴出に移行したものと考えられる。

元山地区の火砕岩の延長と考えられるものは釜岩，阿蘇台断層崖，阿蘇台宿没口，ミリオンダラー火口， 千鳥ヶ原火口・宿没口，千鳥ヶ原中央部付近の道路の切取部などで認められる。したがって，千鳥ケ原一 帯は漂流砂磷に覆われているものの，その下位にはこの火砕岩が存在する事は明らかである。地質図には その確認された範囲を破線で示した。

摺鉢山は直径約 $1 \mathrm{~km}$, 海拔 $161 \mathrm{~m}$ ，山頂に火口をもつ截頭円錐丘である。地質は下位より軽石火山硳凝灰 岩一角磁岩, 粗面安山岩溶岩, 最上部にスコリアと凝灰岩の互層から成る火砕丘が載る（一色 1976）。

軽石火山角碩岩は大まかな層理をもち, 軽石片と発泡度の低い黒色ガラス質本質岩片（黒曜石）とから なり，異質の石質岩片が極めて少量などの特徵から陸上噴火による陸上降下堆積物ではない（一色 1976）。 粗面安山岩溶岩は厚さ20-30mで, 南南西にゆるく傾斜し, 摺鉢山の全周に露出している。下位の凝灭岩一 


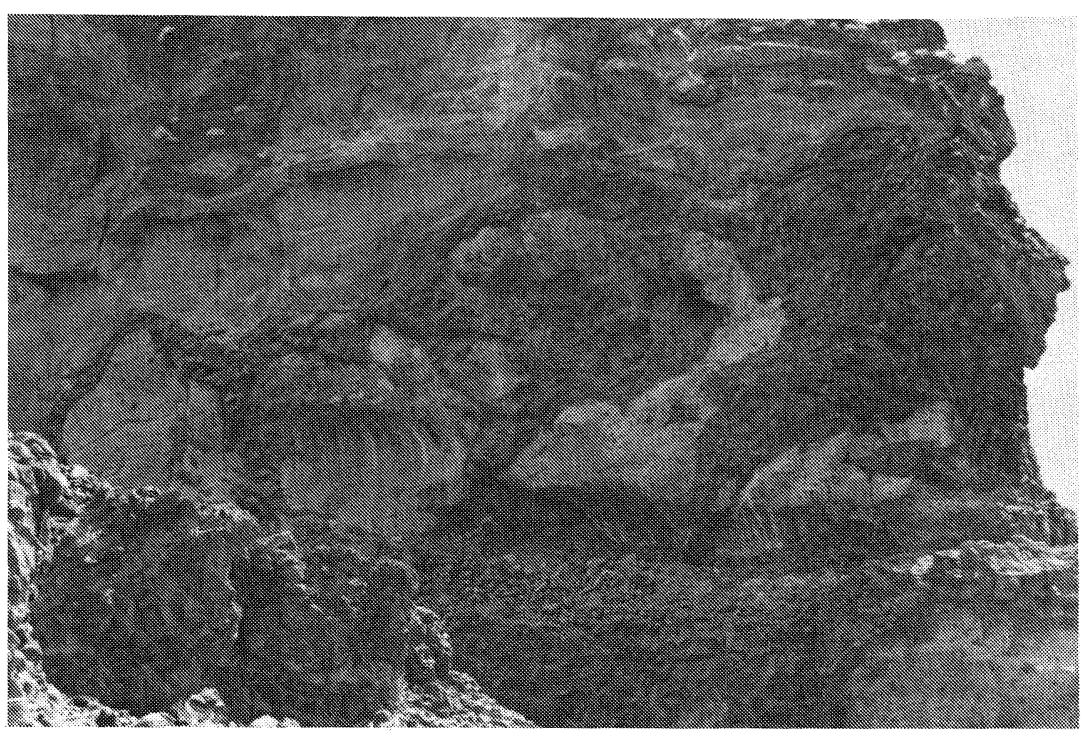

写真 4 元山火砕岩中を脈状に貫ぬく元山溶岩 為八海岸西端部の海食崖。

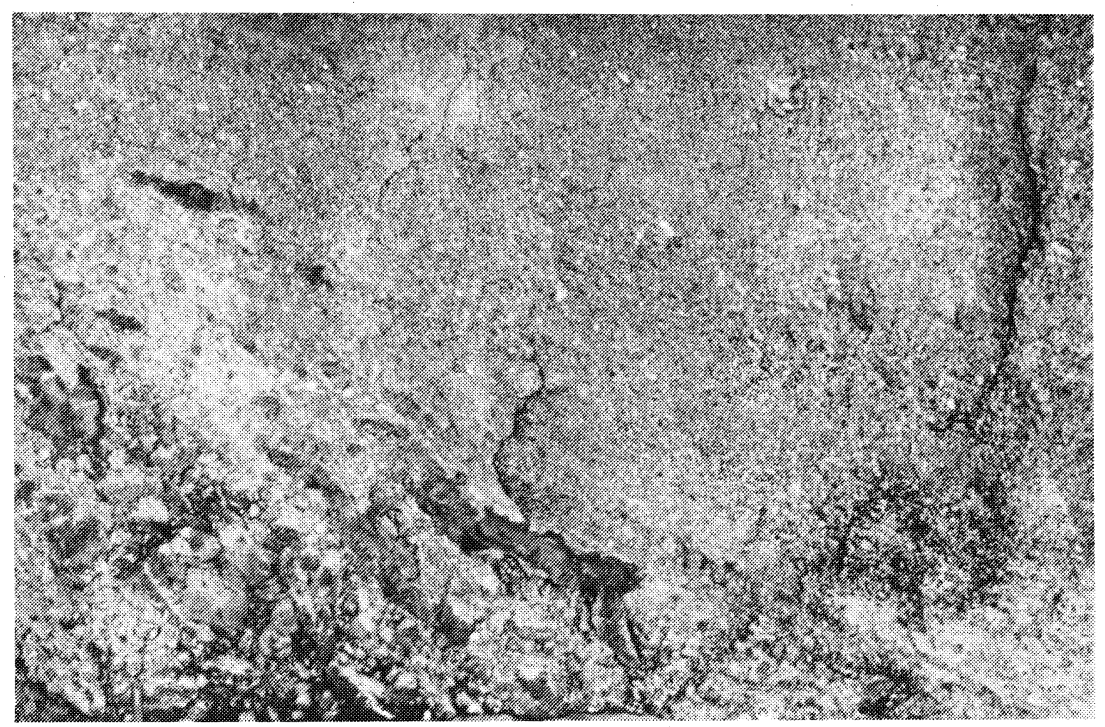

写真 5 元山火砕岩中にとり込まれた元山溶岩の破片（本質岩片） 為八海岸

右上方は火砕岩, 左下部では黒色の溶岩片が長く引き伸ばされて火砕岩中にとり込まれている。

角砅岩との間に砂質シルト層が狭在する場合があり，同層に熱による変色を与えていない点から，溶岩流 の下底は水中であったと考えてよい（一色 1976）。最上位の火砕丘を構成するスコリアと凝灰岩の互層 は，溶岩との境界面では，溶岩流の表面の凹凸に平行な層理を持って堆積している。これより，火砕丘は 陸上で形成されたと考えられる（一色 1976）。摺鉢山の北北西海岸には軽石角磁岩にアバットし，淘汰の やや良好な層理のある軽石火山磁一火山灰が認められ，水中堆積物と考えられている（一色 1976）。 


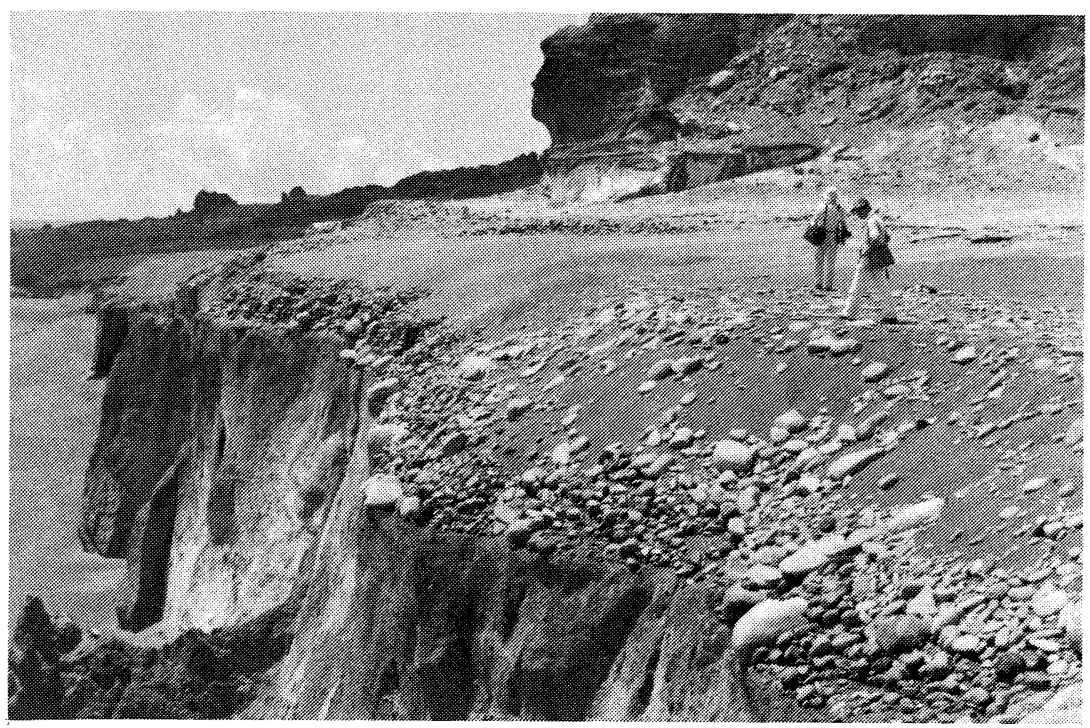

写真 6 元山の段丘砅層 箱庭浜

黒い礫は溶岩, 白い磁は火砕岩, 下の海食崖は元山火砕岩の下部層

元山地区と摺鉢山地区との地質層序関係は，直接的証拠では確認されていない。しかし，両地区の溶岩 は後述のように化学組成，鉱物組成ともよく類似しており，同一マグマ源か，ほぼ同時期に噴出した可能 性は高い。

島の周囲には多数の海成段丘が発達しており，2．2節に詳述されている。これらの段丘面上には溶岩， 火研岩の円磁を含む砂礫層が数 $10 \mathrm{~cm}$ 数 $\mathrm{m}$ の厚さで載る場合が多い。また，摺鉢山周辺の段丘上にはサン ゴの砂，とくに礁状サンゴの磁も認められた。

元山地区の台地上には，所々に礁状サンゴの着生が知られている（豊島 1932, SwENSON 1948）。し かし, 同島返還後, その確認された位置は元山温泉と眼鏡岩との中間地点のみである (大八木・熊谷 1977) (後述)。

\section{II. 火山岩の特幑}

硫黄島の火山岩に関する岩石学的研究（本間 1925, 津屋 1936a，b，岩崎 1937）によると，元山お よび摺鉢山両地区に産する溶岩の化学組成 (第 9 章参照) は, ともに $\mathrm{SiO}_{2}$ が58 60\%, $\mathrm{Na}_{2} \mathrm{O} 6 \%$ 前後, $\mathrm{K}_{2} \mathrm{O} \quad 4 \%$ 前後であり, 粗面安山岩と呼ばれている。その他の成分では $\mathrm{FeO}$ と $\mathrm{Fe}_{2} \mathrm{O}_{3}$ の量が多少異なる 以外はほぼ同じ組成を示し，両者は同質のマグマ起源と考えられる。第 1 章でも述べられているように, アルカリ岩の産出は，この硫黄島とその南の $2 ， 3$ の火山に限られ，注目されている。

元山地区および摺鉢地区の粗面安山岩溶岩の鏡下の特徴を一色（1976）の記載から要約する。両地区の 溶岩は斑晶鈗物に直径 $1 \mathrm{~cm}$ に達する板状の斜長石（アンデジン）を特徴的に含み, かんらん石, 普通輝 石，鉄鉱，隣灰石を共通的に含む。石基は元山地区の溶岩では極めて細粒でオリゴクレス，単斜輝石，ア ルカリ長石，燐灰石が識別され，粒度の差による流理構造が認められる。一方，摺鉢山地区の溶岩は完晶 質の石基を持ち，含有鉱物は元山溶岩と同じであるが，アルカリ長石はオリゴクレスを取り囲んで産する。 そのほか，小量のエジリン，Z 軸が黄褐色の角閃石およびクリストバル石が含まれる。

火砕岩中の本質岩片はガラス質であるが，斑晶鉱物組成は溶岩と同じである。細粒なガラス質凝灰岩は 
長さ $3 \mathrm{~mm}$ 以下, 長く伸びた気孔を有する軽石片からなる。軽石片はモンモリロナイトに変り, 軽石片表 面や気孔壁には魯卵状の方沸石が，その表面には針状のモルデン沸石が付着し，岩石の固結に寄与してい る(一色 1976)。

\section{III. ${ }^{14} \mathrm{C}$ 年代測定}

硫黄島北部，北の鼻海岸付近で大八木・熊谷（1977）は火砕岩中から炭化木片 4 個を採集した。これら から2670 2860年 B.P.の ${ }^{14} \mathrm{C}$ 年代值を得た。以上の年代值より，元山の火砕岩堆積年代は，およそ2700 ２800年 B.P.という事になる。大八木・熊谷（1977） は前述のように炭化木片の産出層準が，火砕岩の 上部層と下部層の境界付近にあり，下部層が一部陸化した状態での流木打上げという木片混入機構を考え たが，これは必ずしも長い時間間隙を必要としない。また，下部層とその下位の粗面安山岩との関係にも 大きな時間差がないとすれば，東海岸，および為八海岸に露出する溶岩から火砕岩最上部へかけての形成 年代も，上記の年代から大きく距たらないと考えられる。

次に，前述の元山・眼鏡岩中間点のサンゴ試料は火砕岩の表面に着生したサンゴであり，かつて，元山 地区が海水面下にあった時に着生したものである。3 個の試料から得られた ${ }^{14} \mathrm{C}$ 年代值は $525 \sim 770$ 年 B.P. である(大八木・熊谷 1977)。試料採集地点の標高は $108 \mathrm{~m}$ ，海水面付近から 770 年間に現在の位置まで上 昇したとすると，この間の元山地区の平均隆起速度は $14 \mathrm{~cm} / \mathrm{yr}$. となる。この值は小坂ら（1974）の推定し た1911 1952年の 41 年間の平均隆起速度 $11 \mathrm{~cm} / \mathrm{yr}$. に近く, 1952 1968年の16年間の平均隆起速度 $31 \mathrm{~cm} / \mathrm{yr}$. の約半分であり，オーダーとしてはこれらの值と同じである。また，これは，現在の急速な隆起は数 100 年 以上前から継続した現象であることを示すものである。

摺鉢山周囲の段丘碟層中から得られたサンゴ礫からは295 2980年 B.P. と広範囲の值が得られた（大八 木・熊谷 1977)。段丘磞層中のサンゴ砂は段丘形成年代よりも古いものが堆積する場合が十分にあり，し たがって最も若い年代值が段丘形成年代に近い。295年 B.P.のサンゴ礫は海抜 $10 \mathrm{~m}$ の段丘碩層である。こ れより，摺鉢山付近の平均隆起速度は $3 \mathrm{~cm} / \mathrm{yr}$. となる。この值は元山地区の值に比し，1桁小さい值であ り，隆起速度に関する現在の傾向とも一致している。

\section{IV． 海岸線の変動}

硫黄島の海岸線は短期間に大きく変化している。第 1 図は1911年以降 6 時期の地形図により海岸線の変 化を示している (釜岩付近の状況の詳細は4. 1参照)。これらの図から, 本島の面積は70年間次第に搪大し ていることがわかる。拡大が著しい地帯は釜岩を含む西海岸，東海岸および南海岸である。これら 3 地帯 は主に砂浜であり，岩石海岸では変化が小さい。釜岩周辺の海岸変化は特に著しく，1911年当時は釜岩は 海岸から約 $1 \mathrm{~km}$ 沖合にあったが1969年頃陸蘩島となり, 以後, 台風の影響により多少の消長を繰り返え しながら次第に砂洲の幅が広大し, 現在に至っている。これらの海岸線変化の原因は漂砂の影響もあるが, 砂の供給は本島以外少らは考えられない事から，基本的要因は本島の著しい隆起によると考えられる（4 章参照)。これを裏づける事実は，千鳥ケ原の北西，東南の両海岸における陸地拡大の著しい部分が隆起の 激しい元山地区に片寄っていることである。釜岩付近で広大したのは，釜岩の隆起とともに，釜岩の存在 により砂の堆積が加わったためと考える。

\section{V. 地質構造および断層变動}

元山地区では，火研岩の層理は台地状部ではほぼ水平，海岸近くで $5^{\circ}$ から $10^{\circ}$ 海側へ傾斜している。 節理系に関しては，未だ系統的な調査が行われていないが，巨視的に見て放射状，および同心円状に発達 しているとみられる。以上から，元山地区はドーム状構造をなすと見られている（一色 1976）。しかし， 


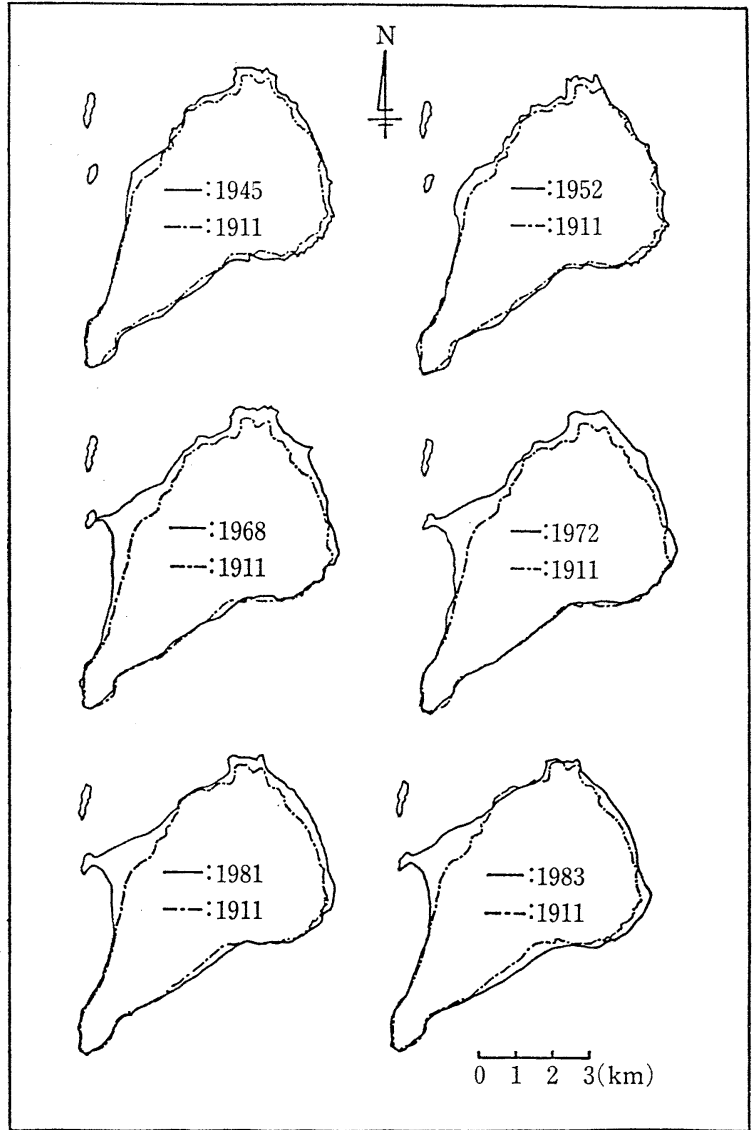

第 1 図 硫黄島の海岸線の変化（1911年の海岸線との 比較, SHIGEMURA (1985)による)
台地状部の地表は, 元山噴気帯の標高116 mの小丘をのぞけば, 中央部分が $105 \mathrm{~m}$, 台地周辺部に117.6, 119.5(東山), 119.8 （玉名山） $111 \mathrm{~m}$ (大坂山）など $110 \mathrm{~m}$ を 越す丘陵があって, 中央の低い皿状地形 を呈している。これは，辻ほか (1969) による最近の地盤垂直変動量の傾向（元 山地区全体の隆起量は大きいが中央部は やや小さい）と調和的である。

\section{1) 断 層}

硫黄島は数 100 年以上前から現在も進 行中の著しい隆起とともに, 地表では著 しい断層変動が認められる。本間(1925) は海岸での隆起に関しては記録している が，断層変動には触れていない。現在の 断層変動を最初に指摘したものは CORWIN and FOSTER (1959) で，現在の 阿蘇台断層上に数個の火口が並ぶことや 千鳥ヶ原の断層群を地質図に記入してい る。

硫黄島返還後, 断層の調査は精力的に 行われ，とくに高橋・熊谷 $(1976 b)$ は 「火山列島の火山現象調查図 $(1 / 10,000)\rfloor$ に現地踏查による断層の分布とその方 向, 落差を示している。また, 森本ら （1968）は旧千鳥飛行場の断層群の落差 を測量し，その後，小坂ら，熊谷らによ り経時変化が追われた。

硫黄島で認められる主な断層, 断層群は第 2 図に示されている。それらは, (1) 旧千鳥飛行場の断層群, （2）千鳥ケ原西側の断層群，（3）阿蘇台断層（高橋ら 1975）とその西側の断層群，(4）天山（元山地区） 南断層群，(5) 摺鉢山周辺の断層群などである。

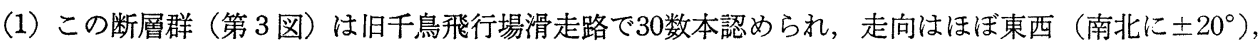
落差は最大 $150 \mathrm{~cm}$ ある。落差の大きいものには北側から A 〜 F*の記号が付されている（森本ら 1968）。 $\mathrm{A}$ 断層は落差最大のものであり，東西に約 $1,200 \mathrm{~m}$ 追跡できる。断層の落ち方向は，まちまちであるが， C およびD断層の中間を境として，全体として千鳥ケ原の東側中央部で最も低く，これより北側では南落ち 量が大きく，南側では北落ち量が大きい。これは，辻ら（1969）の水準測量による元山地区の大きな隆起 量に対する千鳥ヶ原での隆起量が小さい事などに対応している。

滑走路跡南西端には千鳥ヶ原火口の東側に NNE-SSW の走向を持ち，西落ち $70 \mathrm{~cm}$ の断層が約 $850 \mathrm{~m}$ にわたり追跡される。この断層は1957年の千鳥ケ原火口の噴火（水蒸気）と関係が哚いとみられている (CORWIN and FosTER 1959)。

*このうち, 断層 $\mathrm{F} は$ 後に確認できなくなった。また, 最近, 同地区は採石・採土, 土砂置場として 利用され多数の断層は覆われ確認が困難になった。 


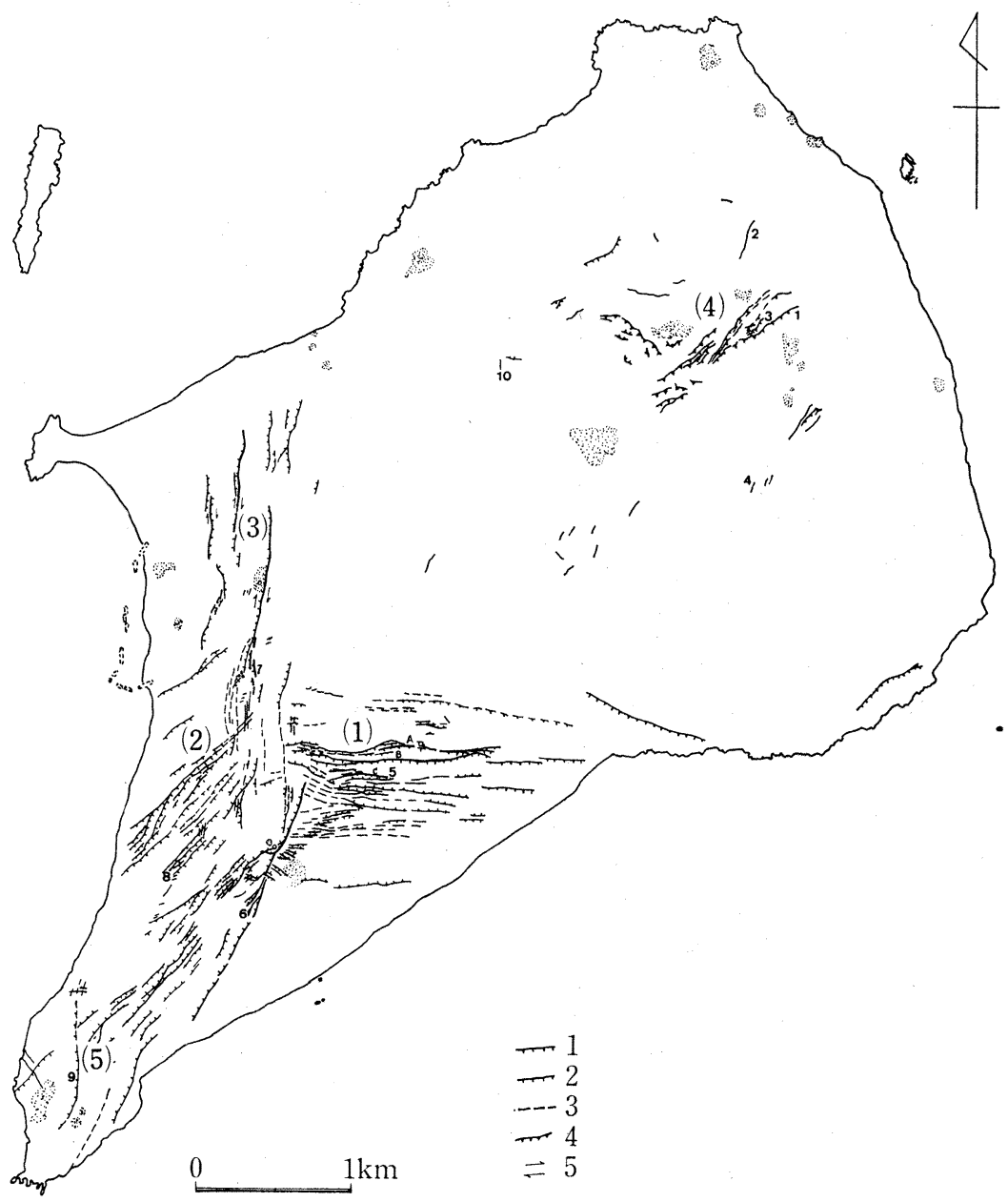

第 2 図断層分布図

本図は高橋・熊谷 $(1976 \mathrm{~b}$ ), 大八木・熊谷 (未発表)の地上踏査結果および空中写真判読により 作成した。1：主要な断層， 2 : 断層（空中写真により落し方向の判読できるもの）, $3:$ 断層 (空中写真で落差は判らないが，断層であることの確実なもの），4：逆断層，5：横ずれ成分を 伴うもの（右ずれの場合が確認されている）。図中の1 10は断層変位計（4．2章参照）の設置点。 点の集合している地域は主な変質帯。(1)～(5) 断層地帯（本文参照）

（2）千鳥ケ原西側の道路およびその西側の海岸斜面を切る断層群は NE-SW の走向を示し，落差は最 大20数 $\mathrm{cm}$ で大きくはない。また，旧千鳥飛行場の断層群との連続性は認められていない。

（3）阿蘇台断層は元山地区の南西部から千鳥ケ原北西部へかけて約 $1500 \mathrm{~m}$ 追跡され，これらの地区と釜 岩・千鳥ケ浜地区とを区切る地溝帯（以下，阿蘇台地溝帯と呼ぶ）の東縁断層である。落差は西落ちで200 $\mathrm{cm}, 50 \mathrm{~cm}$ 程度の開口も認められる。また, この断層に沿って, あるいは接近して, ミリオンダラー火口, 阿蘇台侔没口など火口が並んでおり, 噴気, 水蒸気爆発もしばしば発生している。この断層, および, 阿 蘇台地溝帯北部の数本の断層は正断層で最大 $256 \mathrm{~cm}$ (阿蘇台断層) 数 $10 \mathrm{~cm}$ の落差を持つとともに右ずれ 成分を有し, 石油パイプライン台石の変位から 1945 年頃以降約 $20 \mathrm{~cm}$ の右ずれが推定される。阿蘇台断層 


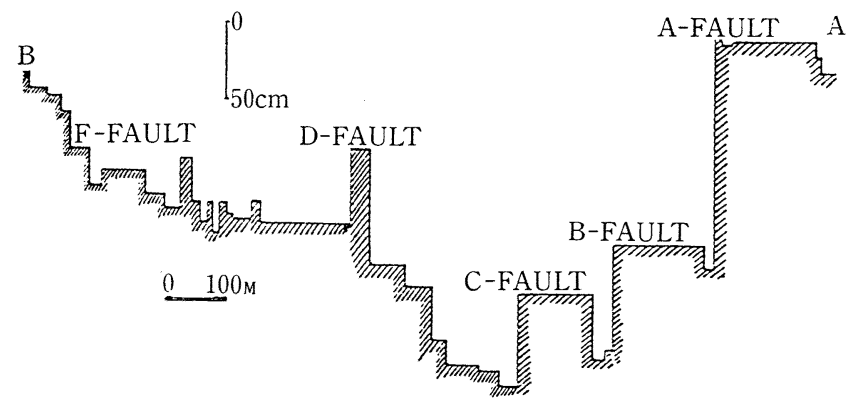

第 3 図千鳥ケ原台地旧千鳥飛行場第 1 滑走路の断層落差断面図 (高橋・熊谷 1976)
の水平変位観測から，阿蘇台陥 没口からの水蒸気爆発が予測 できることも明らかになった (TAKAHASHI et al. 1976b)。

(4) 天山南のアスファルト舗 装面, 旧北飛行場東部およびそ の南方には，走向ほぼ $\mathrm{E}$ 一Wな いし, ENE-WSW の逆断層 群が分布する。全体として南落 ち，北から南への押し上げが確 認される。アスファルトの押し 覆せから推定される水平変位量 は数 $10 \mathrm{~cm}$ 以下, 垂直変位量は $10 \mathrm{~cm}$ 以下で小さい。この逆断層群は, 後に考察するように北の鼻付近で 16年間に $9 \mathrm{~m}$ ，元山中央部で $5 \mathrm{~m}$ （辻ら 1969）の差だけでは発生し得ず，上部地盤を南北方向に圧縮す る力が作用しなければならない。

（5）摺鉢山山頂付近からほぼ北へ延びる断層，および，西側海岸線で NW-SE に走る断層群が認めら れる。前者は正断層で, 西落ち最大 $65 \mathrm{~cm}$ である。その延長上, 周回道路の彎曲部に $\mathrm{N}-\mathrm{S}$ 系の断層が数 本雁行状に走り, ともに西落ち正断層である。後者, 西側海岸の断層は開口亀裂で, 開口幅 $25 \mathrm{~cm}$ に達す る(高橋・熊谷 1976)。

\section{2）断層と地質構造}

以上，概観した断層あるいは断層群と地質構造との関係を考察する。

まず，（4）の天山南方の逆断層群は前述のように明らかに北から南への低角の押し上げによるもので, 北の鼻地区の本島最大の上昇量によると考えるが，ここで北の鼻地区の隆起は単に垂直成分のみでなく, 南微東方向へ押す水平成分む含まれるのではないかと考える。阿蘇台断層は幅 $300 \mathrm{~m}$ に達する阿蘇台地溝 帯の東縁を限るとともに, 最大 $200 \mathrm{~cm}$ の落差があり, 数 $10 \mathrm{~cm}$ も開口しており, かつ, 右ずれ成分を持 つ。しかも, この地溝帯内で, 同地溝帯の延長方向（北微東一南微西）に走る断層には明らかに右ずれ成 分をもつものがある（右ずれ最大 $50 \mathrm{~cm}$, その断層の垂直落差 $150 \mathrm{~cm}$ )。すなわち, この地溝帯は, 単なる地 溝帯ではなく, 元山地区と釜岩地区とが相対的に右ずれ変位している地帯でもある。釜岩における垂直変 位量は元山地区に比し著しく小さいこと，および，釜岩地区は海中に没しているカルデラの外輪山に近い 位置にあることを考え合わせると，釜岩の水平変位量も元山地区の水平変位量に比して小さいと考えられ る。したがって, 元山地区の方がより大きく水平変位しているにちがいない。すなわち, 元山地区は下方 からの押し上げによる急速な隆起とともに，南への押しによる南への変位も行っていると考える。

千鳥ケ原西側の道路を横切る小断層群のうち，その北部の断層群（ミリオンダラー火口の南）は阿蘇台 断層または同地溝帯の延長で, ほぼ南北に近い走向を持つものが多く, その南部では, 北東一南西の走向 を持つ断層が大部分となる。この断層系は, 阿蘇台断層をはじめ同地溝帯の南北方向断層が不鮮明になっ た付近より現われている。これは，地溝帯の南への延長方向にあたる地帯において作用した右ずれ成分の シンプルシアーに対応した小断層であると位置づけられる。すなわち, 千鳥ケ原西側の 2 方向の断層群は ともに元山地区の上昇のみならず，南への変位に関係した応力配置で説明できる。

旧千鳥飛行場を切る断層群はほぼ東西の走向を持ち, 落差も大きいものが多いことは前の通りである。 ところで，これらの断層は厳密には正断層か逆断層かは確認されていない。しかし，開口したものは1968 年の調査では認められていない (熊谷貞治氏談話)。また, 1976年の大八木・熊谷による断層追跡調査（未 公表）でも，最西端部の 1 例を除いて，開口した断層法認められていない。これらのことから，旧千鳥飛 
行場の断層群は隆起しながら南へも押して来る元山地区の前面に発生した断層群と考えても矛盾はない。 辻ら（1969）による16年間の垂直上昇量は元山地区南部（6 m) が摺鉢山北麓におけるより $3 \mathrm{~m}$ 大きく, この差が， $\mathrm{A} \sim \mathrm{F}$ 断層（森本ら 1968）などの大きな落差を生じた原因と考えてよい。ところで，これら の断層群の落ち方向は系統的ではない。この点からみると,これらは逆断層系の断層である可能性もある。

高砂台断層は阿蘇台地溝帯の延長上に位置しており, 阿蘇台断層とは雁行上の位置関係にある。ここで は横ずれ成分については確認されていないが，落ち方向は，阿蘇台断層と同じ西落ちである。

以上を要約すると，元山地区，千鳥ヶ原地区および釜岩地区を含む硫黄島の大部分の地域における断層 系の生成と変位は，元山地区北部（北の鼻付近）から南への押し上げによる元山地区全体の変動によると 考えた。なお，最近の千鳥ケ原における， 3 年間で約 $30 \mathrm{~cm}$ の上昇量は, 元山地区のみの変動によるもの か, 千鳥ケ原における独立の変動に起因するか今後の検討課題としたい。

摺鉢山を切る南北性の断層は，ほぼすべて西落ちである。これらの断層群は阿蘇台地溝帯の延長上では ない。さらに西側に, 海底地形図 (国土庁・国際航業 1982) で認められる地溝状の谷の延長上に位置し ている。別の見方としては，落差 $65 \mathrm{~cm}$ の主断層は火口付近より南へは追跡されていないが，飛石鼻の北 北西 $200 \mathrm{~m}$ 付近へ延びる亀裂につながる疑いもある。この場合には，この断層は大きな基岩クリープ（後方 回転の成分をもつ）の頂部の亀裂ということになる。なお，摺鉢山西海岸中央部やや北で認められている $\mathrm{NW}-\mathrm{SE}$ 系の開口性の “断層” は，小規模な基岩クリープ（また璂岩すべり）による亀裂と考える。

最近の変動としては，1982年に地震発生回数の著しかった時期に，千鳥ヶ原地区において既存の断層 37 本において新しい落差が生じた。その変位は，従来の傾向に調和的であった。なお，阿蘇台断層は約 $50 \mathrm{~cm}$ 開口が認められたが，他の断層は開口していなかった（熊谷・高橋 1983a）。

\title{
VI. あとがき
}

硫黄島の地質, 地質構造, 地史および最近の地盤変動とくに断層の分布, 相対的動き, 海岸線の変化を 概観してみた。ここで問題になるのは，南への押しを含む北部の隆起が何に起因するかである。海上保安 庁（1981）による海上の磁気調査では本島の北に高い全磁気異常が表われており，この地帯の意味は重要 な手掛りになるものと考えられる。断層の変動は噴気活動の活性化, ときに水蒸気爆発の原因となるのか, あるいは，結果であるのか，今後の本島における火山活動の傾向を予測する上でも，また，深部の地質構 造を知る上でも重要であり, 今後の研究の発展に期待したい。

\section{4 硫黄島島内における試錐調査}

$$
\text { 小坂 丈 予* 小沢竹二郎** 平 林 順 - }{ }^{* * *}
$$

\section{Survey of Trial Hole on Iwo-jima}

Joyo Ossaka, Takejiro OzAwA and Jun-ichi HIRABAYASHI

\begin{abstract}
The hole with the depth of $150 \mathrm{~m}$ was drilled at Motoyama area. From ground surface

* 東京工業大学工学部 (現在岡山大学理学部) Faculty of Engineering, Tokyo Institute of Technology (Faculty of Science, Okayama University)

** 埼玉大学工学部 Faculty of Engineering, Saitama University

*** 東京工業大学工学部 Faculty of Engineering, Tokyo Institute of Technology
\end{abstract}

